\title{
Jaundice during pregnancy: maternal and fetal outcome
}

\author{
Jayanthi Krishnamoorthy ${ }^{1}$, Anuradha Murugesan ${ }^{2 *}$
}

\author{
${ }^{1}$ Department of Obstetrics and Gynaecology, Government Tiruvannamalai Medical College, Tiruvannamalai, \\ Tamilnadu, India \\ ${ }^{2}$ Department of Obstetrics and Gynaecology, SRM Medical College, Kattankulathur, Tamilnadu, India
}

Received: 17 June 2016

Accepted: 05 July 2016

\section{*Correspondence:}

Dr. Anuradha Murugesan,

E-mail: anuthanigai@yahoo.com

Copyright: () the author(s), publisher and licensee Medip Academy. This is an open-access article distributed under the terms of the Creative Commons Attribution Non-Commercial License, which permits unrestricted non-commercial use, distribution, and reproduction in any medium, provided the original work is properly cited.

\begin{abstract}
Background: Jaundice affects a small percentage of pregnant women, yet it takes a major toll on health of both mother and fetus especially in developing countries like India. Jaundice in pregnancy carries a grave prognosis for both the fetus and the mother, and is responsible for $10 \%$ of maternal deaths. The aim of the study was to find out the effect of jaundice during pregnancy on maternal and fetal outcome.

Methods: 51 pregnant women with jaundice during pregnancy attending the Institute of obstetrics and gynaecology, Egmore, Chennai between 2011-2012.

Results: 51 patients had jaundice during pregnancy. The incidence of jaundice was $0.29 \% .74 \%$ of patients was between 20-29 years of age. Maximum numbers of cases were Primigravida. The most common cause of jaundice was Viral Hepatitis. Maternal mortality was $7.8 \%$.The common maternal complications were atonic postpartum haemorrhage $9.8 \%$, hepatic encephalopathy $7.87 \%$, disseminated intravascular coagulation $5.88 \%$ and hepatorenal failure $4 \%$. Perinatal mortality was $35.5 \%$.

Conclusions: Jaundice in pregnancy has adverse fetomaternal outcome. Improvement in health awareness, education and regular antenatal checkups, early referrals result in early diagnosis and treatment of jaundice during pregnancy thus reducing maternal and fetal mortality and morbidity.
\end{abstract}

Keywords: Jaundice, Pregnancy, Viral hepatitis, Morbidity, Mortality

\section{INTRODUCTION}

Jaundice affects a small percentage of pregnant women, yet it takes a major toll on health of both mother and foetus especially in developing countries like India. Jaundice in pregnancy carries a grave prognosis for both the fetus and the mother, and is responsible for $10 \%$ of maternal deaths. ${ }^{1}$ It could be peculiar to the pregnancy such as acute fatty liver of pregnancy, recurrent cholestatic jaundice in pregnancy and jaundice complicating toxemia of pregnancy. It can be concurrent with pregnancy such as due to infective pathology like viral hepatitis or due to gallstones or it could be due to drugs administered during pregnancy. The present study analyses the cause of the disease, altered liver function, maternal and fetal morbidity and mortality and preventive measures in jaundice complicating pregnancy. This study will be helpful in better understanding and improving the maternal and perinatal outcome in jaundice complicating pregnancy.

\section{METHODS}

The study was conducted in Institute of obstetrics and gynaecology, Egmore, Chennai, India from 2011 to 2012. This prospective study of maternal and fetal outcome included 51 pregnant women with jaundice admitted in Institute of obstetrics and gynaecology during the study 
period. Elaborate history and thorough general, systemic and obstetric examination were carried out. Liver function tests like serum bilirubin total, direct and indirect, total proteins, albumin and globulin, serum transaminases, serum alkaline phosphatase, clotting time, bleeding time and ultrasonogram, complete hemogram, reticulocyte count, coagulation profile, viral markers study including HBs Ag, Anti HAV IgM, Anti HCV Ab, Anti HEV IgM were done in all patients. Dark field microscope examination and IgM (ELISA) were done for leptospirosis. Maternal outcome was noted in terms of the mode of termination of pregnancy, maternal morbidity and mortality. Fetal outcome was assessed by perinatal morbidity and mortality.

\section{RESULTS}

Total number of antenatal admissions during this period was 17,890 . Total number of patients with jaundice was 51. The incidence of jaundice complicating pregnancy during this period in the hospital was $0.29 \%$. The patients in the study group were in the age range from 18 years to 36 years. Nearly $74 \%$ of the jaundiced patients were between 20 and 29 years. The incidence of jaundice was more common in low socio-economic groups. About 92.1 of cases belonged to class IV and V. Maximum numbers of cases were Primigravida 54.9\% and second gravida were $35.29 \%$. Out of 51 cases, 41 cases $(80.39 \%)$ presented with jaundice during III trimester (Table 1).

Table 1: Demographic profile.

\begin{tabular}{|lll|}
\hline Age group (years) & No. of cases & Percentage \\
\hline $15-19$ & 5 & 9.8 \\
\hline $20-29$ & 38 & 74.51 \\
\hline $30-40$ & 8 & 15.69 \\
\hline S.E class & \\
\hline III & 4 & 7.84 \\
\hline IV & 24 & 47.06 \\
\hline V & 23 & 45.1 \\
\hline Gravidity & & \\
\hline Primigravida & 28 & 54.9 \\
\hline Multi gravida & 23 & 45.1 \\
\hline Period of gestation & & \\
\hline I Trimester & 2 & 3.92 \\
\hline II Trimester & 8 & 15.69 \\
\hline III Trimester & 41 & 80.39 \\
\hline
\end{tabular}

3 Patients had history of contact with jaundice. 2 patients had history of blood transfusion among which one was HBsAg positive. 5\% of patients were utilising safe water for drinking purpose and $95 \%$ were ignorant about safe water. On analysing the presenting symptoms $86.27 \%$ had high coloured urine. Nausea and vomiting were present in $70.6 \%$ of patients. Other predominant symptoms were fever, loss of appetite and upper abdominal pain. Jaundice was present in all the cases. Other signs were hepatomegaly, splenomegaly, scratch marks and Ascites (Table 2).
Table 2: Clinical features.

\begin{tabular}{|lll|}
\hline Symptoms & No. of cases & Percentage \\
\hline High coloured urine & 44 & 86.27 \\
\hline History of fever & 20 & 39.21 \\
\hline Loss of appetite & 23 & 45.09 \\
\hline Nausea and vomiting & 36 & 70.58 \\
\hline Upper abdominal pain & 18 & 35.29 \\
\hline Itching & 3 & 5.88 \\
\hline Clay stools & 3 & 5.88 \\
\hline Abdominal distension & 7 & 19.6 \\
\hline Clinical signs & & \\
\hline Jaundice & 51 & 100 \\
\hline Hepatomegaly & 9 & 17.64 \\
\hline Splenomegaly & 4 & 7.8 \\
\hline Scratch marks & 3 & 5.88 \\
\hline Ascites & 4 & 7.84 \\
\hline
\end{tabular}

$92.15 \%$ of patients showed positive for bile pigments and bile salts in the urine. $19.6 \%$ patients were positive for Protein. The level of S. bilirubin varied widely between 2.8 to $18.4 \mathrm{mg} / \mathrm{dl} .7 .84 \%$ of patients had high S. bilirubin more than $16 \mathrm{mg} / \mathrm{dl}$. The serum transaminase level was below $100 \mathrm{IU} / \mathrm{L}$ in $13.72 \%$ of patients, $5.88 \%$ patients had level more than $500 \mathrm{IU} / \mathrm{L}$. S. alkaline phosphatase was more than $200 \mathrm{U} / \mathrm{L}$ in $37.25 \%$ (Table 3 ).

Table 3: Liver function tests.

\begin{tabular}{|lll|}
\hline Serum bilirubin $(\mathrm{mg} \%)$ & No.of cases & Percentage \\
\hline $2-5$ & 16 & 31.37 \\
\hline $6-10$ & 21 & 41.17 \\
\hline $11-15$ & 10 & 19.60 \\
\hline $16-20$ & 4 & 7.84 \\
\hline SGPT $($ IU/L) & & \\
\hline$<200$ & 23 & 45.09 \\
\hline $200-500$ & 25 & 49.01 \\
\hline$>500$ & 3 & 5.88 \\
\hline ALP $($ IU/L) & & \\
\hline$<400$ & 40 & 78.42 \\
\hline $400-800$ & 9 & 17.64 \\
\hline$>800$ & 2 & 3.92 \\
\hline
\end{tabular}

Viral hepatitis was the commonest etiology in $50.98 \%$. Out of this, hepatitis E was detected in 14 cases, hepatitis $\mathrm{B}$ in 10 cases. HELLP syndrome was the next common etiology in $13.72 \%$ Acute fatty liver of pregnancy and chronic liver disease and portal hypertension were the cause in $7.84 \%$ each. Hemolytic jaundice due to hereditary spherocytosis was seen in one patient. The cause was undetected in 2 cases (Table 4).

Out of 51 patients 45 delivered. 4 patients who were in second trimester and 1 in first trimester got discharged after treatment. 1 patient died antenatally and one patient underwent therapeutic abortion due to hemolytic crisis. $70 \%$ of patients delivered vaginally. $21.56 \%$ patients had 
LSCS. Out of 45 patients, 23 patients (45\%) had term delivery, 22 patients $(43 \%)$ had preterm delivery (Table 5).

Table 4: Etiology of jaundice.

\begin{tabular}{|lll|}
\hline Diagnosis & No. of cases & Percentage \\
\hline Viral hepatitis & 26 & 50.98 \\
\hline HELLP syndrome & 7 & 13.72 \\
\hline $\begin{array}{l}\text { Intrahepatic cholestasis } \\
\text { of pregnacy }\end{array}$ & 3 & 5.88 \\
\hline $\begin{array}{l}\text { Acute fatty liver of } \\
\text { pregnacy }\end{array}$ & 4 & 7.84 \\
\hline $\begin{array}{l}\text { Chronic liver disease and } \\
\text { portal hypertension }\end{array}$ & 4 & 7.84 \\
\hline $\begin{array}{l}\text { Blood reaction } \\
\text { Leptospirosis }\end{array}$ & 1 & 1.96 \\
\hline Hyperemesis gravidarum & 1 & 3.92 \\
\hline $\begin{array}{l}\text { Hemolytic jaundice } \\
\text { (hereditary } \\
\text { spherocytosis) }\end{array}$ & 1 & 1.96 \\
\hline Undetected & 2 & 1.96 \\
\hline
\end{tabular}

Table 5: Pregnancy outcome.

\begin{tabular}{|lll|}
\hline Pregnancy outcome & No.of cases & Percentage \\
\hline Abortion & 1 & 1.96 \\
\hline Preterm delivery & 22 & 43.13 \\
\hline Term delivery & 23 & 45.09 \\
\hline
\end{tabular}

$35 \%$ of patients developed complications. In four patients hepatic encephalopathy was seen. Atonic PPH was seen in 5 patients. DIC was seen in 3 patients (Table 6 ).

Table 6: Maternal outcome.

\begin{tabular}{|lll|}
\hline Complications & No. of cases & Percentage \\
\hline DIC & 3 & 5.88 \\
\hline Abruption & 2 & 3.92 \\
\hline Atonic PPH & 5 & 9.8 \\
\hline Hepatic encephalopathy & 4 & 7.87 \\
\hline Hepatorenal failure & 2 & 3.92 \\
\hline Oesophageal varices & 2 & 3.92 \\
\hline Total & 18 & 35 \\
\hline Maternal Mortality & 4 & 7.8 \\
\hline
\end{tabular}

Maternal mortality was $7.8 \%$ (4 out of 51 patients) due to jaundice. Among 4 deaths two were due to acute fatty liver of pregnancy, one died of HELLP syndrome and one due to rupture of esophageal varices (Table 7).

Among 4 cases two had S.bilirubin more than $10 \mathrm{gm} / \mathrm{dl}$. Perinatal mortality was $35.5 \%$. Of these $80 \%$ was due to prematurity. There were 45 births $(83.8 \%)$. Of these 22 were preterm and 23 were term babies (Table 8 ).

Poor fetal outcome was seen with HELLP syndrome $31.25 \%$, hepatitis E 25\%, hepatitis B $12.5 \%$, and intrahepatic cholestasis of pregnancy 12.5\%. 24 babies were below $2.5 \mathrm{~kg}$ and among them there was $80 \%$ mortality (Table 9).

Table 7: Causes of maternal mortality.

\begin{tabular}{|llll|}
\hline Diagnosis & $\begin{array}{l}\text { No.of } \\
\text { cases }\end{array}$ & $\begin{array}{l}\text { Maternal } \\
\text { mortality }\end{array}$ & Percentage \\
\hline HELLP syndrome & 7 & 1 & 25 \\
\hline Portal hypertension & 4 & 1 & 25 \\
\hline $\begin{array}{l}\text { Acute fatty liver of } \\
\text { pregnancy }\end{array}$ & 4 & 2 & 50 \\
\hline
\end{tabular}

Table 8: Fetal outcome.

\begin{tabular}{|lll|}
\hline Outcome & Number of cases & Percentage \\
\hline Term live babies & 21 & 46.6 \\
\hline Term IUD babies & 2 & 4.44 \\
\hline Preterm live babies & 12 & 26.6 \\
\hline $\begin{array}{l}\text { Preterm still Birth / } \\
\text { IUD }\end{array}$ & 10 & 22.2 \\
\hline $\begin{array}{l}\text { Born alive and dead } \\
\text { (all preterm) }\end{array}$ & 4 & 8.8 \\
\hline Perinatal mortality & 16 & 35.5 \\
\hline
\end{tabular}

Table 9: Influence of baby weight on fetal outcome.

\begin{tabular}{|lll|l|}
\hline $\begin{array}{l}\text { Baby } \\
\text { weight }(\mathrm{kg})\end{array}$ & $\begin{array}{l}\text { No. of } \\
\text { babies }\end{array}$ & $\begin{array}{l}\text { Neonatal } \\
\text { death }\end{array}$ & $\begin{array}{l}\text { Percentage of } \\
\text { neonatal death }\end{array}$ \\
\hline$<1.5$ & 11 & 9 & 56.25 \\
\hline $1.5-2.5$ & 13 & 4 & 25 \\
\hline $2.5-3.5$ & 20 & 3 & 18 \\
\hline$>3.5$ & 1 & 0 & 0 \\
\hline
\end{tabular}

\section{DISCUSSION}

Total antenatal admissions during the study period were 17890 of which 51 patients had jaundice and the incidence is $0.29 \%$. About $92 \%$ patients belonged to lower socioeconomic class and $86 \%$ were consuming unsafe water. Begum $\mathrm{N}$ et al studied about the seroprevalence (IgG Anti $\mathrm{HEV}$ ) of subclinical HEV infection in pregnant women and reported that exposure to hepatitis E was more in lower socio economic class. ${ }^{2}$

The maximum incidence of jaundice was in $3^{\text {rd }}$ trimester and the complications were also high during that period. Harshad et al, Shukla et al and other studies have stated that maximum incidence of jaundice was in III trimester and morbidity and mortality were also higher during III trimester. ${ }^{3,4}$

In present study, high level of S.bilirubin, SGPT and SGOT levels more than $500 \mathrm{IU} / \mathrm{ml}$ were associated with viral hepatitis. Harshad et al also reported that marked elevation of bilirubin and transaminases (10 fold) occured in viral hepatitis whereas patients with pregnancy associated liver disease like HELLP, Intrahepatic 
cholestasis of pregnancy and hyperemesis had only $2-3$ fold elevation.

Viral hepatitis was the cause in $51 \%$ cases comparable to the study by Shukla et al who reported $57 \%$ and Harshad et al reported $47 \%$ cases of viral hepatitis. ${ }^{3,4} 13.72 \%$ of cases had HELLP syndrome in present study. Rathi $U$ et al reported $52.3 \%$ of cases with liver dysfunction due to preeclampsia and HELLP. ${ }^{5} 4$ cases had chronic liver disease. Among them 3 had noncirrhotic portal hypertension (NCPH). Agarwal et al studied 50 pregnant patients with $\mathrm{NCPH}$ and reported that in $56 \%$ patients NCPH was detected first during pregnancy. ${ }^{6}$ In India it is commonly due to non-cirrhotic portal fibrosis and extra hepatic portal vein obstruction. But in western countries portal hypertension is mostly due to cirrhosis. Intra hepatic cholestasis of pregnancy was diagnosed in 3 patients; one had history of jaundice in her mother during her antenatal period. Study had one case of haemolytic jaundice due to hereditary spherocytosis which underwent therapeutic abortion due to haemolytic crisis. Pajor et al studied 19 pregnancies with hereditary spherocytosis, concluded that pregnancy precipitated hemolytic anaemia and maternal and fetal outcome was favourable after splenectomy. ${ }^{7}$ Leptospirosis was diagnosed in 2 cases by MSAT. Shalini et al reported a case of leptospirosis with Jaundice, coagulopathy and intra uterine death. ${ }^{8}$ One was due to hyperemesis gravidarum. Matsubara's et al reported that Jaundice in hyperemesis is due to biliary sludge and it is relieved by hydration. ${ }^{9}$

In the present study $7.8 \%$ patients died, $35 \%$ patients developed complications and $58 \%$ had uneventful recovery. $9.8 \%$ patients had atonic PPH. 5.8\% had DIVC, $7.8 \%$ had hepatic encephalopathy. Abruption, hepatorenal failure, esophageal varices was seen in $3.9 \%$ each. Jain S et al reported 52 patients with fulminant hepatic failure and concluded that renal dysfunction was the indicator of poor prognosis in patients with fulminant hepatic failure. $^{10}$ Rathi $\mathrm{U}$ et al reported 3 cases of AFLP and among them 2 cases died of DIVC and multiorgan failure. ${ }^{5}$ Third patient died of HELLP syndrome, had severe hypertension, proteinuria, ascites delivered a dead born baby, died of DIVC and hepatorenal failure. Rathi U et al reported $25 \%$ mortality due to preeclampsia associated liver dysfunction. ${ }^{5}$ The fourth patient was a case of non-cirrhotic portal hypertension with grade III esophageal varices died due to massive hematemesis at her second trimester. West brook et al reported one death in pregnancy due to variceal bleeding. ${ }^{11}$

Mortality due to viral hepatitis was not seen in the present study though many patients of hepatitis $\mathrm{E}$ had severe morbidity. Study by Jayanthi et al, observed that mortality rate of hepatitis $\mathrm{E}$ infection in southern India was very low 3-4\% compared to high mortality 30-100\% seen in studies from Northern India. ${ }^{12}$ Study by Harshad et al, reported that mortality was $41 \%$ in pregnancy associated liver disease and $7.5 \%$ in viral hepatitis and concluded mortality due to hepatitis E was low. ${ }^{3}$

Preterm deliveries were $48.8 \%$ (26.6\% live birth and $22.2 \%$ intra uterine deaths). The higher incidence of preterm delivery was supported by Kumar et al $66.6 \%$ and Harshad et al $32 \%$ is due to high fever, increased cytokine release, disturbed hormonal status and debilitating effects of viremia of hepatitis. ${ }^{13,3}$ The perinatal mortality in present study was $35.5 \%$ comparable to Rathi $U$ et al who reported $35.4 \%$ and Kumar et al reported 26.5\%.,13 Among 16 Neonatal deaths, HELLP syndrome constitutes $31.2 \%$, hepatitis E $25 \%$, hepatitis B $12.5 \%$, and intrahepatic cholestasis of pregnancy $12.5 \%$. According to Williamson et al the poor fetal outcome in intrahepatic cholestasis of pregnancy was due to the toxic bile acid level in the fetus causing fetal arrhythmia. ${ }^{14}$ One intrauterine death was seen with chronic liver disease. Westbrook et al reported $26 \%$ of fetal loss with chronic liver disease. ${ }^{11} 53.3 \%$ babies were below $2.5 \mathrm{~kg}$ in present study and among them there was $80 \%$ mortality. Shukla et al reported $30.8 \%$ mortality in low birth weight babies. ${ }^{4}$

\section{CONCLUSION}

Although liver dysfunction is infrequently seen in pregnancy, it can result in severe maternal and fetal compromise. Viral hepatitis is the most common cause of jaundice in pregnancy. Generating public awareness about the various routes of transmission of the different types of infective hepatitis, improving sanitary conditions and habits, imparting health education and knowledge of preventive measures, routine and regular antenatal checkups and viral markers as a part of routine antenatal screening can help in reducing the burden of jaundice in pregnancy. Jaundice in pregnancy should be managed as a team with collaboration of obstetrics, internal medicine, gastroenterology, anaesthesia and critical care so that early diagnosis and aggressive management can prevent and reduce fetomaternal morbidity and mortality.

\section{Funding: No funding sources \\ Conflict of interest: None declared}

Ethical approval: The study was approved by the Institutional Ethics Committee

\section{REFERENCES}

1. Tripti N, Agarwal S. Fetomaternal outcome in jaundice during pregnancy. Obstet Gynecol India. 2005;10:424-7.

2. Begum N, Devi SG, Husain SA, Kumar A, Kar P. Seroprevalence of subclinical HEV infection in pregnant women from north India: a hospital based study. Indian J Med Res. 2009;130:709-13.

3. Harshad D, Walter KK, Ross D, Lakshmi P. Pregnancy-associated acute liver disease and acute viral hepatitis: differentiation, course and outcomes. Journal Hepatology. 2008;49:930-5. 
4. Shukla S. Prospective study on acute viral hepatitis in pregnancy; seroprevalence, and fetomaternal outcome of 100 cases. J Biosci Tech, 2011;2(3):27986.

5. Rathi U, Bapat M, Rathi P, Abraham P. Effect of liver disease on maternal and fetal outcome-a prospective study. Indian J Gastroentero. 2007;26:59-63.

6. Aggarwal N, Sawhney H, Vasishta K, Dhiman RK, Chawla Y. Non-cirrhotic portal hypertension in pregnancy. Int J Gynaecol Obstet. 2001;72(1):1-7.

7. Pajor A, Lehoczky D, Szakács Z. Pregnancy and hereditary spherocytosis report of 8 patients and a review. Arch Gynecol Obstet. 1993;253(1):37-42.

8. Gainder S, Singla R, Dhaliwal L, Suri V. Leptospirosis as a cause of intrauterine fetal demise: short report of rare presentation materno-fetal. Med Archives Gyneco Obst. 2010;281(6):1061-3.

9. Matsubara S, Kuwata T, Kamozawa C, Sakamoto Y, Suzuki M, Tamada K. Connection between hyperemesis gravidarum, jaundice or liver dysfunction, and biliary sludge. Trop Gastroenterol. 2000;21(3):118-20.

10. Jain S, Pendyala P, Varma S, Sharma N, Joshi K, Chawla Y. Effect of renal dysfunction in fulminant hepatic failure. Indian J Med Res. 2009;130(6):70913.

11. Westbrook RH, Yeoman AD, Ogrady JG. Model for end-stage liver disease score predicts outcome in cirrhotic patients during pregnancy. Clin Gastroenterol Hepatol. 2011;9(8):694-9.

12. Rasheeda CA, Udayakumar N, Jayanthi V. Diseases in pregnancy and its influence on maternal and fetal mortality-a prospective study from Chennai, southern India. Eur J Gastroenterol Hepatol. 2008;20:362-6.

13. Kumar A, Beniwal M, Kar P, Sharma JB, Murthy NS. Hepatitis E in pregnancy. Int J Gynaecol Obstet. 2004;85(3):240-4.

14. Williamson C, Miragoli M, Kadir S. Bile acid signaling in fetal tissues: implications for intrahepatic cholestasis of pregnancy. Dig Dis. 2011;29(1):58-61.

Cite this article as: Krishnamoorthy J, Murugesan A. Jaundice during pregnancy-maternal and fetal outcome. Int J Reprod Contracept Obstet Gynecol 2016;5:2541-5. 